\title{
PERANCANGAN DAN PEMBUATAN PURWARUPA LINE FOLLOWER FORKLIFT
}

\author{
Mochammad Aji Adi Wibowo ${ }^{1}$, Fachrudin Hunaini ${ }^{2}$, Dedy Usman Effendi ${ }^{3}$ \\ ${ }^{1}$ Fakultas Teknik, Jurusan Teknik Elektro, Universitas Widyagama Malang \\ ${ }^{2}$ Fakultas Teknik, Jurusan Teknik Elektro, Universitas Widyagama Malang \\ 3 Fakultas Teknik, Jurusan Teknik Elektro, Universitas Widyagama Malang \\ Email: ajiadiwibowo@ymail.com
}

\begin{abstract}
Abstrak
Forklift merupakan perangkat yang digunakan sebagai alat memuat barang (Loading) dan menurunkan muatan (unloading) yang sangat dibutuhkan dalam proses suatu perodoksi. Hanya saja Forklift ini masih memiliki kelemahan, yakini masih di operasikan secara manual. Prototipe line follower forklift merupakan perpaduan antara sistem Forklift yang merupakan sistem konvensional dan robot line follower yang merupakan sistem otomatis. Fungsi dari alat ini adalah mengambil barang dan menaruh barang ke target pilihan yang telah ditentukan. Dalam pembuatan proyek akhir ini jumlah yang berfungsih sebagai tempat pengambilan barang berjumlah satu ruang stanby, dan jumlah target yang berfungsi untuk meletakan barang ada tiga ruang storage, untuk kebutuhan posisi target dapat di ubah sesuai dengan kebutuhan, hanya saja harus diperlukan pengubahan program. Kenerja dari prototipe line follower forklift ini dapat berjalan dengan baik, hal ini terbukti dari pengujian 80\%, hanya saja ada beberapa faktor yang mempengaruhi kinerjanya, factor-faktor yang mempengaruhinya antaranya factor kebersihan lantai, factor intensitas cahaya, factor tinggi rendah lantai.
\end{abstract}

Kata kunci: Forklift, Prototipe line follower forklift.

\begin{abstract}
Forklift is a device that is used as a tool to load goods (Loading) and reduce load (unloading) that is needed in the process of a perodoxy. It's just that this Forklift still have weakness, it is believed that it is still manually operated. The line follower forklift prototype is a combination of a Forklift system which is a conventional system and a line follower robot which is an automated system. Function of this tool is to take the goods and put the items to the specified target. In making this final project, the number that functions as a place to collect goods amounts to one standard room, and the number of targets that function to place the goods are three storage rooms, for target position needs can be changed according to needs, only program changes must be needed. The performance of the line follower forklift prototype can work well, this is evident from $80 \%$ testing, it's just that there are several factors that affect its performance, the factors that influence it include the cleanliness of the floor, the light intensity factor, the low floor height factor.
\end{abstract}

Keywords: Forklift, Prototype line follower forklift. 


\section{PENDAHULUAN}

Mobile Robot adalah konstruksi robot yang ciri khasnya adalah mempunyai aktuator berupa roda untuk menggerakkan keseluruhan badan robot tersebut, sehingga robot tersebut dapat melakukan perpindahan posisi dari satu titik ke titik yang lain [1], dapat dibuat sebagai Robot Line Follower sederhana merupakan suatu bentuk robot bergerak otonom yang mempunyai misi mengikuti suatu garis pandu yang telah ditentukan [2], Robot Line Follower sederhana pada bagian bawah mempunyai sensor tracking, sehingga dapat mengetahui keberadaan tracking untuk jalan robot. Robot Line Follower nsederhana mempunyai karakteristik 3 Degree of Freedom (DOF) derajat kebebasan gerak maju, gerak belok kiri, dan gerak belok kanan [3].

Forklift atau disebut juga forklift truck adalah suatu alat yang terdiri dari Body (badan) dan Work Equipment (peralatan kerja) yang digunakan untuk memuat barang (Loading) dan menurunkan muatan (unloading) fungsi utamanya sebagai alat transportasi pengangkat barang-barang yang bisa digunakan pada industri untuk memindahkan barang ke ruang, penyimpanan barang dengan 4-DOF yaitu gerak maju dan mundur, gerak belok kanan dan belok kiri, dan gerak Fork untuk membawa atau mengangkat barang, sedangkan gerak Mast berfungsi untuk Lifting danTilting [4].

Permasalahan saat ini forfklift masih menggunakan operator untuk mengemudikannya, dan kegiatan operator forfklift saat ini bekerja untuk mengantar barang menjadi cepat dan otomatis maka sebab itu, operator forfklift tidak di pekerjakan, oleh karena itu dibutuhkan penambahan sistem otomatis pada forfklift dengan membuat Line Follower sebagai lintasan yang ditentukan. Gerakan Loading dan unloading yang terprogram di dalam mikrokontroler tersebut, sehingga secara garis besar fungsi Prototipe Line Follower Forklif ini untuk memindahkan barang.

Pada skripsi ini dirancang dan dibuat Prototipe Line Follower Forklift untuk melakukan gerakan mekanik sebanyak 4-DOF yaitu gerak maju dan belok mengikuti tracking, dan gerakan loading dan unloading. Forklift mempunyai komunikasi wireless untuk pengantar barang pada masing-masing ruang storage, dan mempunyai 2 (dua) mikrokontroler 8535, dan 2 (dua) wireles radio frekuensi YS1020UA. Mikrokontroler 8535 di gunakan pada kontrol ruang storage dan kontrol Forklift, wireles radio frekuensi YS-1020UA digunakan komunikasi pada ruang storage dan komonikasi pada Forklift.

\section{STUDI PUSTAKA}

\subsection{Mikrokontroler AVR atmega 8535.}

Mikrokontroler AVR memilki arsitektur RICS 8 bit, dimana semua instruksi dikemas dalam kode 16-bit dan sebagian besar adalah IC mikrokontroler dengan tegangan rendah, teknologi terbaru dari PEROM (Programable Erase Read Only Memory). Alat ini dibuat oleh ATMEL dengan tingkat ketelitian tinggi [5]. Penjelasan Fungsi Pin Mikrokontrtoller AVR ATMEGA 8535 Mikrokontroller ini memiliki 40 konfigurasi pin seperti digambarkan pada Gambar 2 Fungsi dari tiap-tiap pin dapat dikelompokkan menjadi sumber tegangan, kristal, kontrol dan input-output.

Disamping itu Mikrokontroler ini dapat ditambahkan sebuah minimum memori eksternal atau komponen eksternal lain. Dari kedelapan line dapat digunakan sebagai suatu unit yang berhubungan ke perangkat parallel seperti printer, pengubah digital ke analog, dan sebagainya, atau tiap line dapat mengoperasikan 
sendiri ke perangkat single bit seperti saklar, LED, transistor, solenoid, motor, dan speker [6].

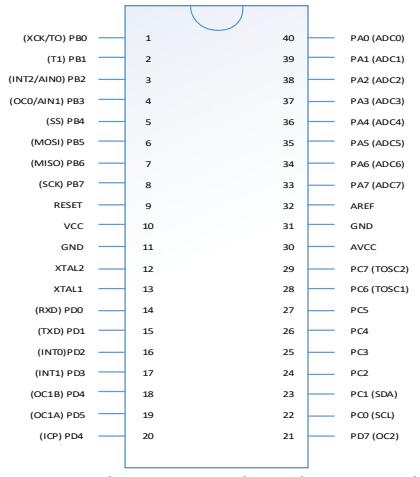

Gambar 2.1 Konfigurasi Kaki IC Mikrokontroler AVR ATMEGA 8535

\subsection{Limit switch.}

Limit Switch merupakan sensor yang prinsip kerjanya menyerupai saklar. Limit Switch mememiliki dua keadaan normal yaitu normally open dan Normally Close. Normally Open dimana salah satu kontak akan aktif jika tombolnya tertekan. Konstruksi dan simbol limit switch dapat dilihat seperti gambar di bawah [7].
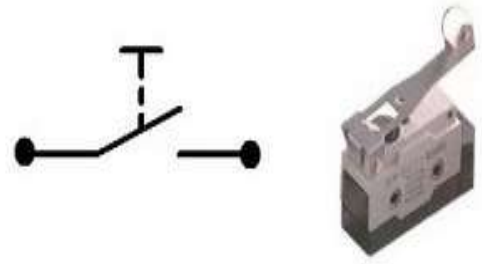

Gambar 2.2 Limit Switch

\subsection{Sensor tcrt 5000 .}

TCRT 5000 adalah komponen elektronika yang memuat pemancar dan detektor infra merah (infrared) dalam satu komponen terpadu. Konstruksi komponen ini yang kompak diatur sedemikian hingga sumber emisi cahaya infra merah dan komponen sensor / detektonya berada pada arah yang sama, dengan demikian mampu mendeteksi keberadaan objek yang mendekat dengan cara mendeteksi pantulan sinar merah yang terpancarkan dan memantul pada permukaan objek tersebut. Keluaran sensor ini dapat didefinisikan menjadi dua jenis, sebagai berikut [8]:

1. Tegangan analog DC, mempunyai jangkah 0-5V. Jika foto-transistor dengan TCRT 5000 dapat mendeteksi kerapatan cahaya infra merah lebih baik, maka sensor ini dapat menghantarkan lebih baik pula sehingga tegangan keluaran menjadi tinggi $(H I G H)$. Dengan kata lain, sensor ini dapat mendeteksi kerapatan cahaya rendah.

2. Keluaran sinyal digital, jika sensor dapat mendeteksi kerapatan cahaya lebih baik, maka sensor ini dapat mengirimkan logika " $1^{\text {" }}$ kekeluaran dan mengirimkan logika „0"sehingga mendeteksi kerapatan cahaya rendah. 


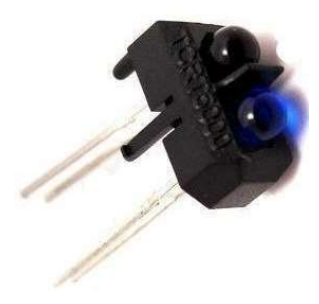

Gambar 2.3 Sensor Warna TCRT 5000.

\subsection{Driver motor H-bridge.}

Rangkaian driver motor DC dengan IC L298 dapat digunakan untuk mengendalikan motor DC dengan arus maksimum hingga 4A. Dengan IC driver motor DC L298 dapat digunakan untuk mngendalikan 2 buah motor DC sekaligus secara independent. Kemampuan tiap driver motor DC dalam IC L298 ini adlah 4A untuk masing-masing drivernya. IC L298 adalah driver motor DC H-Bridge dengan 2 unit driver didalam 1 chip IC. Feature yang dimiliki IC driver motor DC L298 sesuai datasheet adalah [9].

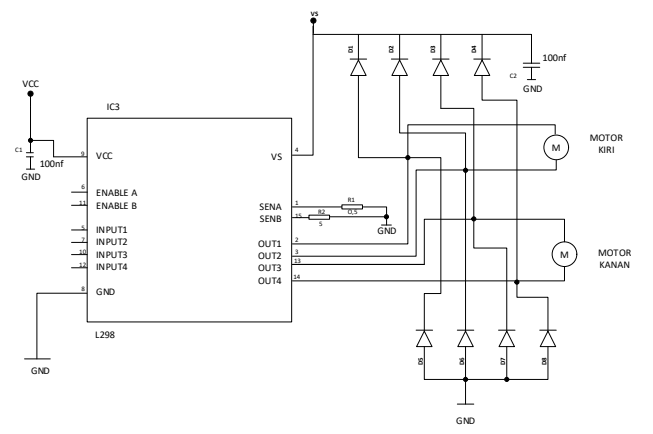

Gambar 2.4 Rangkaian driver motor DC dengan IC L298D.

\subsection{Motor DC.}

Arus yang mengalir melalui sebuah konduktor akan menghasilkan medan magnet. Degnan kaidah tangan kiri, kita dapat menentukan arah Medan magnet. Ibu jari tangan dapat mewakili arah Medan magnet yang timbul, seperti yang ditunjukkan Gambar 2.7 [10].

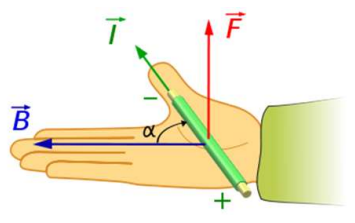

Gambar 2.5 Kaidah tangan kanan.

Dengan ketentuan:

$\mathrm{F}$ = adalah Gaya Lorentz (newton)

$\mathrm{B}=$ adalah Medan magnet (tesla)

$\mathrm{Q}=$ adalah muatan listrik (coulumb)

$\mathrm{v}=$ adalah arah kecepatan muatan $(\mathrm{m} / \mathrm{s})$

$x=$ adalah perkalian silang dari operasi vector. 
Untuk menunjukkan arah arus yang mengalir didalam sebuah konduktor, dapat digunakan kaidah tangan kanan. Jari tengah menunjukan arah arus yang mengalir pada konduktor, jari telunjuk menunjukan arah Medan magnet dan ibu jari menunjukan arah gaya putar, seperti diperlihatkan Gambar 9.

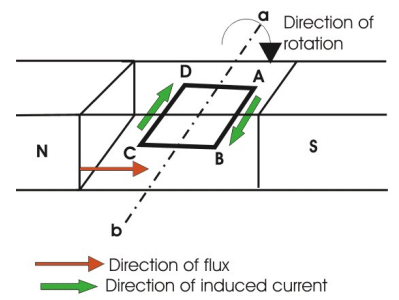

Gambar 2.6 Konstruksi Dasar Motor DC

\subsection{Wireless radio frekuensi YS-1020UA (YS-1020UB).}

YS-1020UA series Low Power RF Moduledidesain untuk sistem transmisi data UART jarak dekat. YS-1020UAmerupakan adaptasi Texas Instruments (Chipcon) CC1020 RFIC, bekerja pada ISM frequency band, transmisi half duplex. Modul dapat langsung tersambung dengan monolitik prosesor, PC, perangkat RS485, dan komponen UART lain dengan RS232, RS485, dan TTL interface port. YS-1020UB merupakan modul komunikasi yang sangat aman, mempunyai 8 kanal dengan frekuensi yang berbeda, frekuensi yang digunakan pada sistem ini adalah 433 Mhz. Jarak jangkauan [11].

Komunikasi sekitar 800 meter pada baud-rate 9600 bps dan maksimum 2000 meter dengan baud-rate1200 bps.

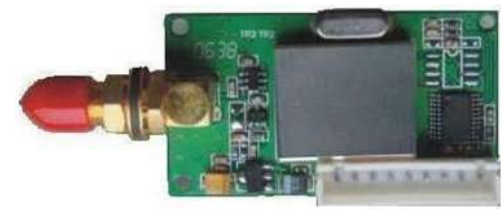

Gambar 2.7 Modul RF YS-1020UA

\subsection{Rangkaian regulator.}

Rangkaian regulator berfungsi sebagai filter tegangan agar sesuai dengan keinginan. Oleh karena itu biasanya dalam rangkaian power supply maka IC.Regulator tegangan ini selalu dipakai untuk stabilnya outputan tegangan. Rangkaian penyearah sudah cukup bagus jika tegangan ripple-nya kecil namun ada masalah stabilitas. Jika tegangan PLN naik/turun, maka tegangan outputnya juga akan naik/turun. Seperti rangkaian penyearah di atas, jika arus semakin besar ternyata tegangan DC keluarnya juga ikut turun. Untuk beberapa aplikasi perubahan tegangan ini cukup mengganggu, sehingga diperlukan komponen aktif yang dapat meregulasi tegangan keluaran ini menjadi stabil. 


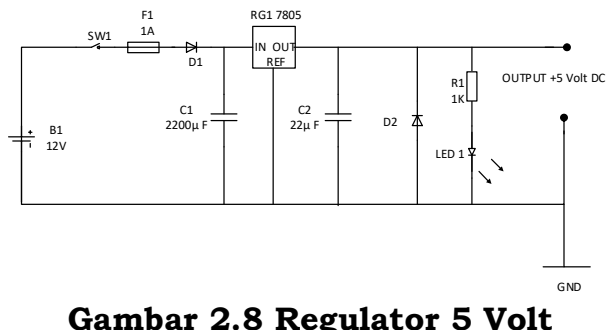

\section{METODE}

\subsection{Blok diagram control.}

Pada blok diagram kontrol Prototipe Line Follower Forklift, menggunakan dua blok diagram kontrol pada ruang storage dan Prototipe Line Follower Forklift pada masing-masing blok diagram kontrol mempunyai satu Mikrokontroler, dan radio frekuinsi YS-1020UA untuk menggabungkan komunikasi pada ruang storage dan Prototipe Line Follower Forklift.

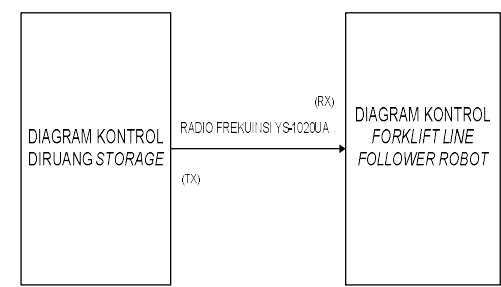

Gambar 3.1 Blok Diagram Kontrol.

\subsubsection{Blok diagram kontrol diruang strorage.}

Sistem kontrol yang diterapkan pada ruang storage menggunakan radio frekuensi YS-1020UA untuk mengirim data dan mengetahui di ruang storage ada barang apa tidak dan data diterima oleh Prototipe Line Follower Forklift. Pada ruang barang hasil produksi diberi lampu indikator untuk membantu mengontrol diruang storage ada barang atau tidak dan masing-masing ruang storage pada rak diberi sensor Limit Switch untuk mendeteksi pada rak ada barang apa tidak, ini digambarkan diagramnya blok pada ruang storage:

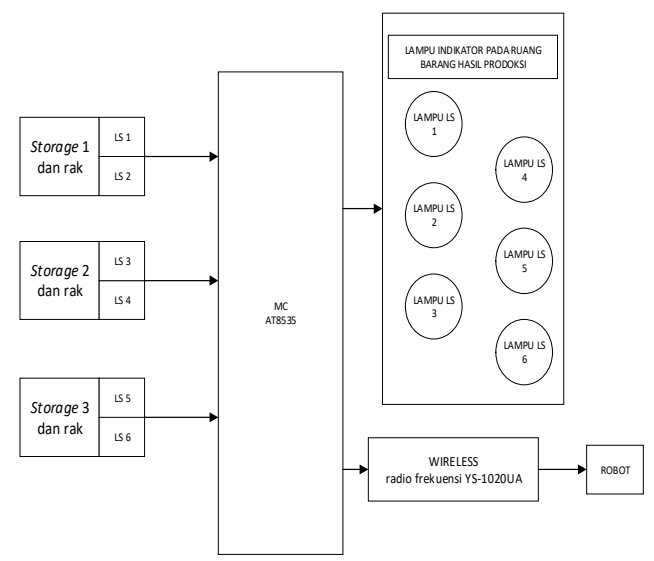

Gambar 3.2 Blok Diagram Kontrol Diruang Strorage 


\subsubsection{Blok diagram kontrol Prototipe Line Follower Forklift.}

Sistem kontrol yang diterapkan pada Prototipe Line Follower Forklift menggunakan radio frekuensi YS-1020UA menerima data untuk mengetahui di ruang storage ada barang apa tidak dan sensor TCRT5000 di gunakan mendeteksi tracking untuk jalannya robot, sensor Limit Switch mengendalikan pergerakan motor DC dari penggerakan Forklift maju mundur, naik ke atas turun ke tengah, dan turun ke bawah. Motor dc roda untuk gerak perpindahan robot dari satu titik ke titik yang lain, ini digambarkan diagramnya blok pada Prototipe Line Follower Forklift.

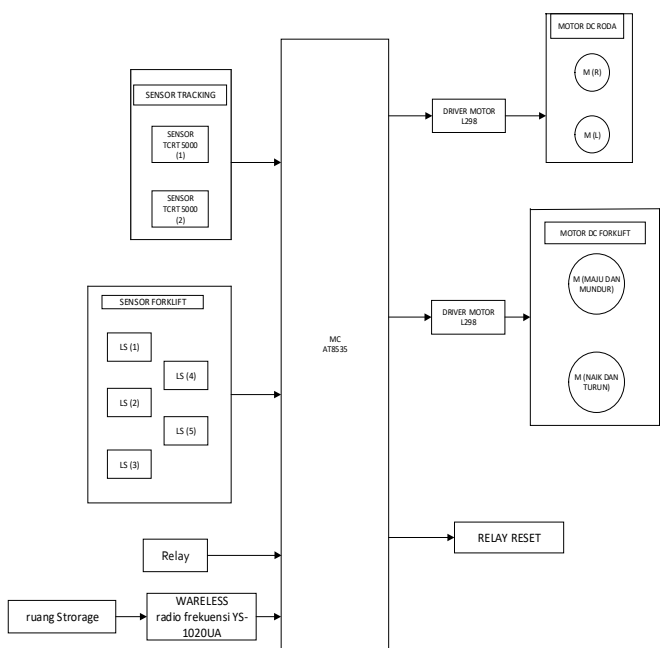

Gambar 3.3 Blok Diagram Kontrol Forklift Line Follower Robot.

Keterangan:

1. Sensor yang digunakan sitem kontrol pada ruang strorage: limit switchch, mikrokontroler, lampu, radio frekuensi YS-1020UA.

2. Sensor yang digunakan sitem kontrol Prototipe Line Follower Forklift: TCRT5000, limit switchch, dan menggunakan tombol push button, mikrokontroler, driver motor dc, motor dc, radio frekuensi YS-1020UA.

\subsection{Line untuk jalanya robot}

Line untuk jalanya robot bentuk line nya ada dibawah ini:

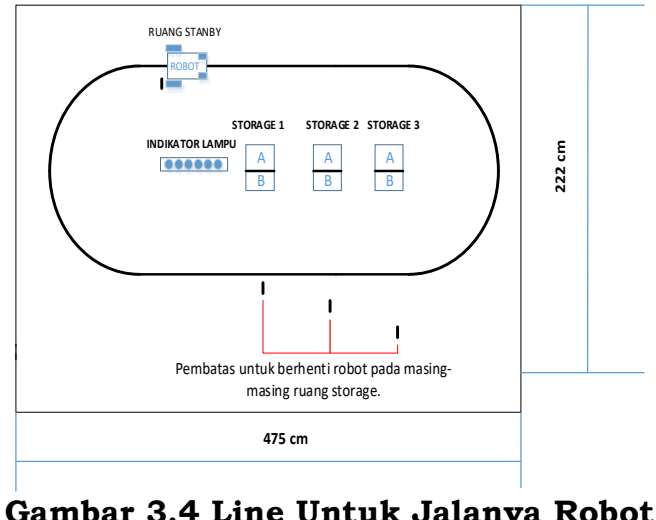

Gambar 3.4 Line Untuk Jalanya Robot 
Pengukuran mekanik Line Untuk Jalanya Robot:

1. Panjang mekanik Untuk Jalanya Robot $=475 \mathrm{~cm}$.

2. Lebar mekanik Untuk Jalanya Robot $=222 \mathrm{~cm}$.

\section{HASIL DAN PEMBAHASAN}

\subsection{Pengujian sensor TCRT5000.}

Sensor TCRT5000 foto transistor infra merah digunakan sebagai pembaca warna hitam dan putih. Hasil pembacaan akan dikonversikan dalam bentuk sinyal listrik. Besar sinyal listrik bergantung pada warna yang di deteksi oleh sensor. Bila sensor mendeteksi warna hitam semakain tinggi (high) tegangan yang di hasilkan, dan apa bila sensor mendeteksi warna putih tegangan yang di keluarkan sensor semakin rendah (low), besaran-besaran keluaran tegangan sensor adalah Volt, alat yang di gunakan pengujian mengukur sensor yaitu multimeter.

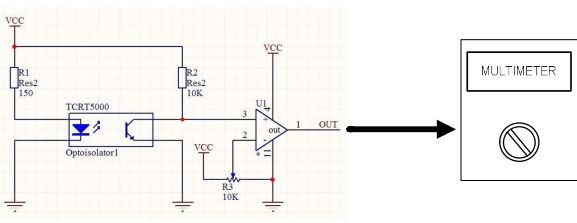

Gambar 4.1 Blok diagram rangkaian pengujian Sensor foto transistor infra merah TCRT5000

Tabel 4.1 hasil pengukuran sensor TCRT 5000.

\begin{tabular}{|c|c|c|c|c|c|}
\hline NO & $\begin{array}{c}\text { SENSOR } \\
\text { TXRT 5000 }\end{array}$ & $\begin{array}{c}\text { SENSOR DETEKSI } \\
\text { WARNA }\end{array}$ & PENGUKURAN & TEGANGAN & ERROR \\
\hline \multirow{2}{*}{1 . } & \multirow{2}{*}{$\begin{array}{l}\text { Sensor TCRT } \\
\text { Lintasan Kanan }\end{array}$} & HITAM (HIGH) & 5 Volt & 5 Volt & $0 \%$ \\
\hline & & PUTIH (LOW) & 0.02 Volt & 5 Volt & $99.6 \%$ \\
\hline \multirow{2}{*}{2.} & \multirow{2}{*}{$\begin{array}{l}\text { Sensor TCRT } \\
\text { Lintasan Kiri }\end{array}$} & HITAM (HIGH) & 5 Volt & 5 Volt & $0 \%$ \\
\hline & & PUTIH (LOW) & 0.02 Volt & 5 Volt & $99.6 \%$ \\
\hline \multirow{2}{*}{3.} & \multirow{2}{*}{$\begin{array}{l}\text { Sensor TCRT } \\
\text { Stanby }\end{array}$} & HITAM (HIGH) & 5.1 Volt & 5 Volt & $-2 \%$ \\
\hline & & PUTIH (LOW) & 0.02 Volt & 5 Volt & $99.6 \%$ \\
\hline \multirow{2}{*}{4.} & \multirow{2}{*}{$\begin{array}{l}\text { Sensor TCRT } \\
\text { Storage } 1\end{array}$} & HITAM (HIGH) & 6.2 Volt & 5 Volt & $-24 \%$ \\
\hline & & PUTIH (LOW) & 0.02 Volt & 5 Volt & $99.6 \%$ \\
\hline \multirow[b]{2}{*}{5.} & \multirow{2}{*}{$\begin{array}{l}\text { Sensor TCRT } \\
\text { Storage } 2\end{array}$} & HITAM (HIGH) & 6.2 Volt & 5 Volt & $-24 \%$ \\
\hline & & PUTIH (LOW) & 0.02 Volt & 5 Volt & $99.6 \%$ \\
\hline \multirow{2}{*}{6.} & \multirow{2}{*}{$\begin{array}{l}\text { Sensor TCRT } \\
\text { Storage } 3\end{array}$} & HITAM (HIGH) & 6.2 Volt & 5 Volt & $-24 \%$ \\
\hline & & PUTIH (LOW) & 0.02 Volt & 5 Volt & $99.6 \%$ \\
\hline
\end{tabular}

Rumus:

\%error $=[($ tegangan $)-($ pengukuran $)] /($ teory $) \times 100 \%$

Perhitungan :

1. Nilai error pembacaan deteksi warna hitam $(5-05,0) / 5 \times 100=0 \%$

2. Nilai error pembacaan deteksi warna hitam $(5-05,1) / 5 \times 100=2 \%$

3. Nilai error pembacaan deteksi warna hitam $(5-06,2) / 5 \times 100=-24 \%$

4. Nilai error pembacaan deteksi warna putih $(5-0,02) / 5 \times 100=99,6 \%$ 


\subsection{Pengujian sensor limit switch}

Untuk mengetahui apakah rangkaian sensor limit switch telah bekerja sesuai dengan yang diinginkan maka dilakukan pengujian rangkaian sensor limit switch. Pengujian dilakukan dengan menekan limit switch dan diukur mengunakan multimeter.

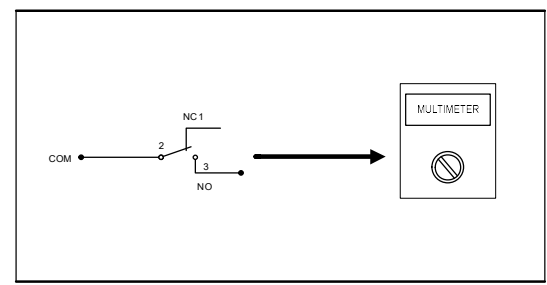

Gambar 4.2 Blok diagram rangkaian pengujian sensor limit switch.

Tabel 4.2 hasil pengukuran sensor limit switch pada Prototipe Line Follower Forklift.

\begin{tabular}{|c|c|c|c|c|c|}
\hline NO & $\begin{array}{c}\text { SENSOR } \\
\text { LIMIT SWITCH }\end{array}$ & $\begin{array}{l}\text { SENSOR } \\
\text { KONDISI }\end{array}$ & PENGUKURAN & TEGANGAN & ERROR \\
\hline \multirow{2}{*}{1.} & \multirow{2}{*}{$\begin{array}{l}\text { Sensor Ls Fork } \\
\text { Atas }\end{array}$} & Sensor OFF & 6 Volt & 5 Volt & $-20 \%$ \\
\hline & & Sensor On & 0 Volt & 5 Volt & $100 \%$ \\
\hline \multirow{2}{*}{2.} & \multirow{2}{*}{$\begin{array}{l}\text { Sensor Ls Fork } \\
\text { Tegah }\end{array}$} & Sensor OFF & 6 Volt & 5 Volt & $-20 \%$ \\
\hline & & Sensor On & 0 Volt & 5 Volt & $100 \%$ \\
\hline \multirow{2}{*}{3.} & \multirow{2}{*}{$\begin{array}{l}\text { Sensor Ls Fork } \\
\text { Bawah }\end{array}$} & Sensor OFF & 6 Volt & 5 Volt & $-20 \%$ \\
\hline & & Sensor On & 0 Volt & 5 Volt & $100 \%$ \\
\hline \multirow{2}{*}{4.} & \multirow{2}{*}{$\begin{array}{l}\text { Sensor Ls Fork } \\
\text { depan }\end{array}$} & Sensor OFF & 6 Volt & 5 Volt & $-20 \%$ \\
\hline & & Sensor On & 0 Volt & 5 Volt & $100 \%$ \\
\hline \multirow{2}{*}{5.} & \multirow{2}{*}{$\begin{array}{l}\text { Sensor Ls Fork } \\
\text { Belkang }\end{array}$} & Sensor OFF & 6 Volt & 5 Volt & $-20 \%$ \\
\hline & & Sensor On & 0 Volt & 5 Volt & $100 \%$ \\
\hline
\end{tabular}

Perhitungan:

1. Nilai error pembacaan pada waktu sensor tidak off $(5-06,0) / 5 \times 100=-20 \%$

2. Nilai error pembacaan pada waktu sensor on $(5-0,00) / 5 \times 100=100 \%$

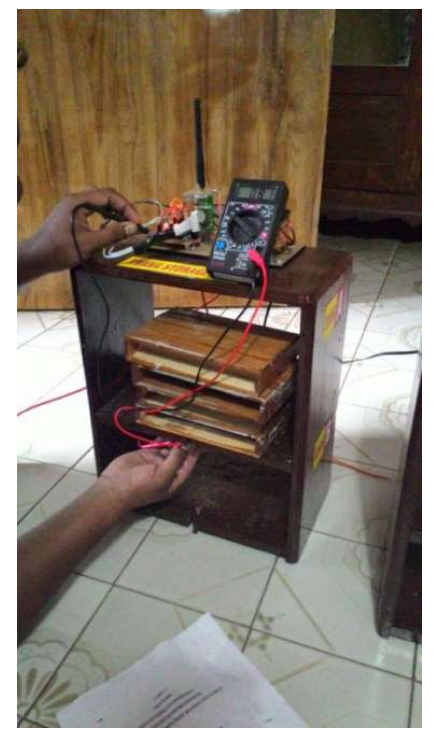

Gambar 4.3 pengujian sensor limit switch pada ruang storage 
Tabel 4.3 hasil pengukuran sensor limit switch pada ruang storage.

\begin{tabular}{|c|c|c|c|c|c|c|}
\hline NO & RUANG & $\begin{array}{l}\text { SENSOR } \\
\text { LIMIT } \\
\text { SWITCH }\end{array}$ & $\begin{array}{l}\text { SENSOR } \\
\text { KONDISI }\end{array}$ & PENGUKURAN & TEGANGAN & ERROR \\
\hline \multirow{4}{*}{1.} & \multirow{4}{*}{$\begin{array}{l}\text { Ruang } \\
\text { Storage } 1\end{array}$} & \multirow{2}{*}{ Sensor LS A } & Sensor OFF & 0 Volt & \multirow{2}{*}{5 Volt } & $100 \%$ \\
\hline & & & Sensor ON & 0.81 Volt & & $0.008 \%$ \\
\hline & & \multirow{2}{*}{ Sensor LS B } & Sensor OFF & O Volt & \multirow{2}{*}{5 Volt } & $100 \%$ \\
\hline & & & Sensor ON & 0.81 Volt & & $0.008 \%$ \\
\hline \multirow{4}{*}{2.} & \multirow{4}{*}{$\begin{array}{l}\text { Ruang } \\
\text { Storage } 2\end{array}$} & \multirow{2}{*}{ Sensor LS A } & Sensor OFF & 0 Volt & \multirow{2}{*}{5 Volt } & $100 \%$ \\
\hline & & & Sensor ON & 0.81 Volt & & $0.008 \%$ \\
\hline & & \multirow{2}{*}{ Sensor LS B } & Sensor OFF & 0 Volt & \multirow{2}{*}{5 Volt } & $100 \%$ \\
\hline & & & Sensor ON & 0.81 Volt & & $0.008 \%$ \\
\hline \multirow{4}{*}{3.} & \multirow{4}{*}{$\begin{array}{l}\text { Ruang } \\
\text { Storage } 3\end{array}$} & \multirow{2}{*}{ Sensor LS A } & Sensor OFF & 0 Volt & \multirow{2}{*}{5 Volt } & $100 \%$ \\
\hline & & & Sensor ON & 0.81 Volt & & $0.008 \%$ \\
\hline & & \multirow{2}{*}{ Sensor LS B } & Sensor OFF & 0 Volt & \multirow{2}{*}{5 Volt } & $100 \%$ \\
\hline & & & Sensor ON & 0.81 Volt & & $0.008 \%$ \\
\hline
\end{tabular}

Perhitungan:

1. Nilai error pembacaan pada waktu sensor off $(5+0,00) / 5 \times 100=100 \%$

2. Nilai error pembacaan pada waktu sensor on $(5-0,81) / 5 \times 100=0,008 \%$

\subsection{Pengujian driver motor DC IC L298.}

Untuk mengetahui apakah rangkaian driver motor DC IC L298 telah bekerja sesuai dengan yang diinginkan maka dilakukan pengujian rangkaian driver motor DC IC L298. Pengujian dilakukan dengan menghidupkan rangkaian driver motor DC IC L298 dan di ukur mengunakan multimeter.

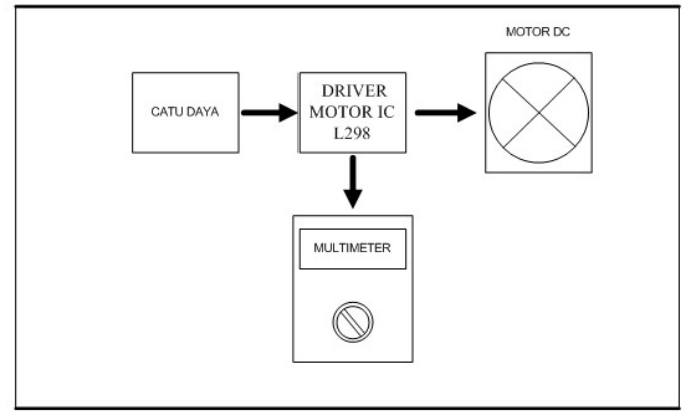

Gambar 4.4 Blok diagram rangkaian pengujian driver motor DC IC L298.

Tabel 4.4hasil pengukuran driver motor DC IC L298.

\begin{tabular}{|c|c|c|c|c|c|}
\hline NO & $\begin{array}{l}\text { SENSOR } \\
\text { LIMIT } \\
\text { SWITCH }\end{array}$ & $\begin{array}{l}\text { PUTARAN } \\
\text { MOTOR }\end{array}$ & $\begin{array}{c}\text { INPUT } \\
\text { TEGANGAN } \\
\text { VS }\end{array}$ & $\begin{array}{c}\text { INPUT } \\
\text { TEGANGAN } \\
\text { VCC }\end{array}$ & $\begin{array}{c}\text { OUTPUT } \\
\text { TEGANGAN } \\
\text { DRIVER }\end{array}$ \\
\hline \multirow{2}{*}{1.} & \multirow{2}{*}{$\begin{array}{l}\text { Driver Motor } \\
\text { Fork }\end{array}$} & Putaran KANAN & \multirow{2}{*}{12 Volt } & \multirow{2}{*}{5 Volt } & 24.4 Volt \\
\hline & & Putaran KIRI & & & 24.4 Volt \\
\hline \multirow{2}{*}{2.} & \multirow{2}{*}{$\begin{array}{l}\text { Driver Motor } \\
\text { Lif }\end{array}$} & Putaran KANAN & \multirow{2}{*}{12 Volt } & \multirow{2}{*}{5 Volt } & 24.2 Volt \\
\hline & & Putaran KIRI & & & 24.3 Volt \\
\hline \multirow{2}{*}{3.} & \multirow{2}{*}{$\begin{array}{l}\text { Driver Motor } \\
\text { Lintasan }\end{array}$} & Putaran KANAN & \multirow{2}{*}{12 Volt } & \multirow{2}{*}{5 Volt } & 24.2 Volt \\
\hline & & Putaran KIRI & & & 24.1 Volt \\
\hline
\end{tabular}




\subsection{Pengujian wireless Radio frekuensi YS-1020UA dan Pengujian keseluruan alat.}

Pada pengujian wireless Radio frekuensi YS-1020UA (Transmitter di hubungkan sistem minimum ATMega 8535. Mengkonekan pada pin masing-masing rangkain langkah pertama sistem minimum ATMega 8535 pin RX TX dihubungkan pada pin RX TX wireless Radio frekuensi YS-1020UA (Transmitter).

Pada pengujian wireless Radio frekuensi YS-1020UA (Receiver) di hubungkan sistem minimum ATMega 8535. Mengkonekan pada pin masing-masing rangkain langkah pertama sistem minimum ATMega 8535 pin RX TX dihubungkan pada pin RX TX wireless Radio frekuensi YS-1020UA (Receiver).

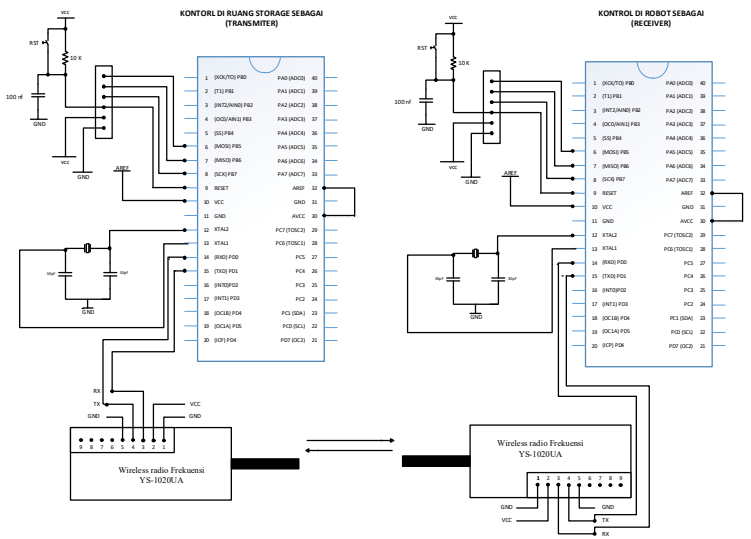

Gambar 4.5 Blok diagram rangkaian pengujian wireless Radio frekuensi YS-1020UA.

\subsection{Rangkaian Keseuruhan Alat.}

Rangkaian elektrik keseluruhan pada pada Prototype Forklift Line Follower Robot.

1. Rangkaian pada robot.

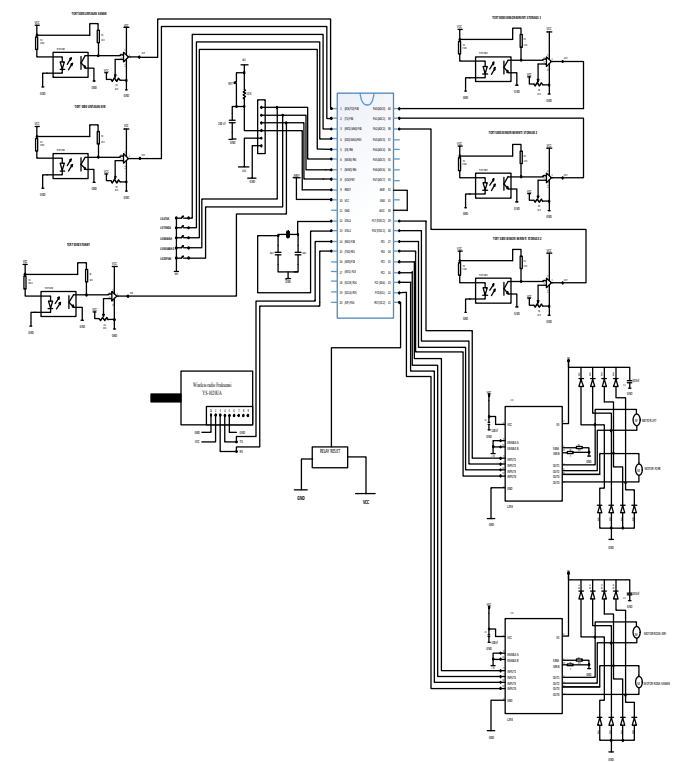

Gambar 4.6 Rangkaian pada robot. 
2. Rangkaian pada rak tempat barang.

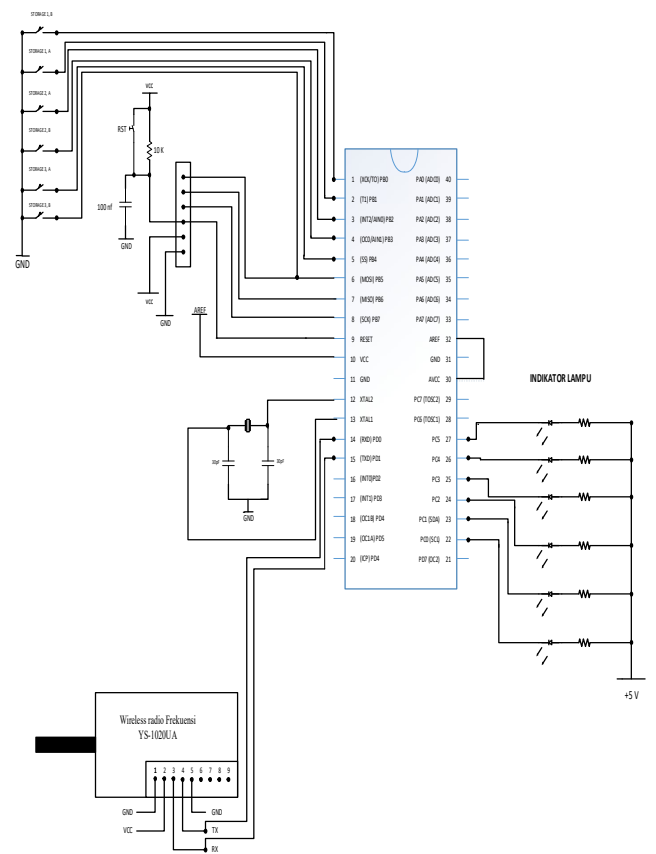

Gambar 4.7 Rangkaian pada rak tempat barang

\section{KESIMPULAN}

Setelah melakukan proses pengamatan dan analisis terhadap sistem yang telah dibuat dapat diambil kesimpulan bahwa :

1. Prototipe Line Follower Forklift mempunyai 2 (dua) mikrokontroler 8535 mikrokontroler dipasang pada kontrol Forklift dan ruang penyimpanan barang (ruang storage) dan 2 (dua) radio frekuensi YS-1020UA dipasang pada Forklift dan (ruang storage) untuk komunikasi pengiriman barang pada masing-masing ruang (ruang storage), sensor TCRT5000 digunakan untuk membaca warana hitam dan putih, dan sensor ini di aplikasikan pada lintasan Line Follower yang berwarna hitam.

2. Prototipe Line Follower Forklift adalah berfungsi sebagai mengantarkan barang dari target satu ke target yang lain. Dalam hal ini dimisalkan memindahkan barang dari ruang storage 1 ke storage lainnya

\section{DAFTAR RUJUKAN}

[1] Prabowo, Y., Hepy, s., 2011. Line Follower Robot Berbasiskan Mikrokontroler Atmel 16. Jurnal Program Studi Sistem Komputer, ISSN: 1693 -9166, Bit Vol, 8 No. 2, September 2011.

[2] Prastya, 2012. Analisis Dan Perancangan Multimedia Pembelajaran Dasar Pembuatan Robot Line Follower. Naskah Publikasi. Jurusan Teknik Informatika Sekolah Tinggi Manajemen Informatika Dan Komputer Amikom Yogyakarta 
[3] Robyn, 2010. Aplikasi Robot Mobil Dalam Pengembangan Prototipe Robot Mobil Wisata. Tugas Akhir. Departemen Teknik Elektro Fakultas Teknik Universitas Indonesia.

[4] Poniman, Yulis, Pneumatik Hidrolik (PH) 'Forklift. Scribd.Com.

[5] Anonim., 2012. Forklift Operator Manual. manual buku. Transport Training Centre.

[6] Anonim., 2008. Forklift Operator's Handbook. manual buku. www.rta.ae.

[7] Sensor tcrt5000 Datasheet.[online]. http://www.vishay.com/docs/83760/tcrt 5000. Diakses tanggal 20 Nopember 2014.

[8] Rofanaharto, 2008. Sistem Pelacak Bus Kampus Dengan Menggunakan Modul DT-51 LCMS Dan Wireless YS1020 RF Data Transceiver. Skripsi. Universitas Indonesa Falkultas Teknik Departemen Elektro.

[9] Ary H., Yudi L., I Komang S., 2011. Perancangan Dan Pembuatan Robot Beroda Dan Berlengan Yang Dilengkapi Dengan Kamera Video Berbasis Mikrokotroler AT89S51. Jurnal Elektro Eltek, ISSN: 2086-8944, Vol. 2 No. 1, April 2011.

[10] Jefta GH, Chairisni L., Prawito P., 2009. Robot Ular Pendeteksi Logam Berbasis Mikrokontroler. Seminar Nasional Teknologi Informasi. Universitas Tarumanagara Jakarta.

[11] Anwar S., Desmiwarman, Nazaruddin N., 2010. Pemakaian Remote Control TV Dengan Menggunakan Mikrokontroler AT89S51 Sebagai Alat Pemutus Dan Penghubung Tegangan Kwh Meter 1 Phasa. Journal Elektron, ISSN: 20856989, Vol 2 No. 2, Desember 2010. 